\title{
The Issue of the Didactic Aspect of the Activity of Play
}

\author{
Alma Tasevska, PhD \\ Assistant professor
}

Ss. Cyril and Methodius University, Faculty of philosophy-Skopje, Institute of pedagogy

\begin{abstract}
The application of the activity of play for educational purposes has caused heated debates among the scientific audience. The content of the didactic games is mainly determined by the program, thus it takes up the shape of a task that should be solved. What is of great significance are the rules that the pupils should follow in order to achieve the desired goal, which is in fact solving the task and finishing the game. In every didactic game, there is the expected result, which on the one hand carries the feeling of satisfaction from the achieved success, while on the other hand, represents a marker of the degree of development. In the orientation of the didactic games, two extremes can be differentiated: The child's development is left fully to the children's spontaneous activities, which are most often the children's self-created games; Didactization of games - its complete transformation and inclination towards strictly directed and previously established educational goals. Hence, the question posed regards whether the activity of game can be freed from its didactic aspect or whether it can be interpreted more freely, in the holistic spirit of contemporary pedagogy. The subject of research in this work is directed towards the didactic aspect of the activity of play. The methods and techniques that were applied are the following: the method of analysis, the inductive, descriptive and the method of generalization, as well as the techniques of analysis of pedagogical documentation, observation and surveying. On the basis of the received results, it can be concluded that: The professional readiness of the teachers is of vital importance to the organization and the realization of the activities of play; Equivalents of the teaching programs are necessary for the realization of the activity of play in the first educational cycle; There is a need for respect towards children's interests, needs and previous knowledge as the foundation in the didactic-methodic preparation of the activity of play; There is need for creating a contemporary concept of didactic materials that shall be applied in the realization of the activity of play.
\end{abstract}

Keywords: didactic aspect, didactic games, activity of play, teaching.

\section{Introduction}

The views regarding the application of the activity of play are divided into 2 streams: on the one hand, there are those that limit the possibilities exclusively to didactic goals, basing play on the concept of traditional teaching; while on the other hand, there are those that interpret its application more widely, or through its influence in several areas, as part of the concept of contemporary teaching based on the active position of the pupil. Both opposing sides offer their own arguments that confirm each view. Didactic games, with such parameters, are not primarily focused on fun or satisfying the needs and interests of the pupils, but are directed rather towards problem solving and satisfying the needs of the program.

The breadth of views, beliefs and interpretations of the activity of play for the purpose of fulfilling didactic goals offers a possibility in the differentiation of the direction and the influence of the activity of play as a methodic concept. This is precisely the core of overcoming the issues in which the activity of play is placed between traditional and contemporary teaching.

This issue can be overcome through the conceptualization of the activity of play that, on the one hand, provides intellectual development, development of social skills, emotional stability and physical maturity, while on the other hand, provides freedom for the pupils in their active position that is not fully anarchic, but in itself contains a structure that is necessary for the process of systematic acquisition of knowledge and abilities, which represents teaching itself. 


\section{Didactic paradigm of the activity of play}

It is thought that didactic games are subordinate to specific educational tasks that have been previously set and contain numerous elements of study. Such activities, with set parameters, do not have the primary function of providing fun for pupils or satisfying the needs and interests of pupils, but they are directed towards problem solving and satisfying the needs of the program.

The state of both tendencies, i.e. both extremes: of spontaneous children's activities of play and activities in which everything has to be determined, where children are not left with any freedom or initiative (Trnavac 1991: 12), are especially important for the pedagogical value of play and the activities of play because through their analysis it should be argumented why they cannot be molded in the extreme of exceptional didactization. The possibility to create a proper balance between the nature of the activity of play and the realization of the program is the core of this issue. The application of the activity of play for didactic purposes mainly aims at both satisfying and increasing pupils' interest in the teaching process, but it should not be the only activity through which the goals and tasks of different program fields are realized. The subtle difference between both courses of the activity of play for didactic purposes is the main reason why it still has not gained the position that it deserves in the teaching practice.

Supporters who doubt the implementaton of the activity of play for didactic purposes also refer to this issue. There are two streams within this orientation: firstly, those who contradict the possibilities for didactic application, and secondly, those who more or less limit the didactic application. Denial of every possibility of the application of play and the activity of play for didactic purposes results from the opinion that play and didactics are two mutually contrasting terms. Play stands for freedom and a causeless activity, while didactics is a structure required for the development of a certain capability, skill, or knowledge, and therefore, play loses its primary function. "Games are considered to be something which cannot be connected to and are quite different from school activities: "a game is an activity which exhausts itself in its own activity, and which does not leave anything behind... On the contrary, a school activity is not selected, but imposed... and, contrary to a game, it leaves its results behind" (Kamenov 1977: 70). This point of view certainly takes an extreme approach to the severe interpretation of the basis upon which both play and didactics are set. The concept of the activity of play is the exact thing which offers the mean value of this point of view and also makes room for a compromise and an internal connection of the different elements of the play and didactics.

However, there are supporters who admit to the existence of certain developmental values of the activity of play for didactic purposes. The argument for this point of view on the part of these supporters is mainly focused towards the criticism of the exceptional impact only on certain features of the pupil.

Both logic and intellect are emphasized, or rather, they exceed the only impact of the intellectual development, which is to be replaced by the holistic approach in the development of the child.

The great distribution of opinions, definitions and interpretations of play and the activity of play for didactic purposes offers an opportunity in the differentiation of the stream and its impact. Hence, it raises the question of whether the activity of play can be free from the didactic prefix or whether it can be interpreted more freely in the holistic spirit of contemporary pedagogy. This is the essence of overcoming the gap which includes the activity of play torn between traditional and modern teaching.

Traditional teaching, in its overall structure, does not really "have faith" in play and the activity of play. The intellectual tendency of the traditional teaching sets play within its own criteria, paying attention only to the benefit from the intellectual developmental changes caused in pupils by the game. The high ranking that strict discipline enjoys in traditional teaching does not offer any opportunity for initiative, activity, creation, or satisfation from the needs, requirements and opportunities of the pupils who are behind the shield of modern active teaching. Discipline in traditional teaching is both a passive and receptive relationship of the pupil. Discipline during play is a result of itself and has the function of a generator or regulator of the activities, hence leading to freedom of the rich and creative pupils' activities. This approach is typical of modern teaching where an active relationship of all of its subjects is promoted. Requirements and opportunities for the implementation of the activity of play in modern teaching is best explained as follows: "Activities of play are vital and have asignificant application in active teaching." They feature this type of teaching and have the role of psychostimulants in the learning processes. The teacher should also use them as a means of a soothing approach to the tasks which should be 
done by the pupil. The components of the activities of play (task of play, content of play, rules of play) are of a highly purpose-built nature and do not always fit a certain program field" (Adamceska 1996: 83).

The activity of play as a methodic concept aims at promotion of the attitude that capabilities, skills and knowledge cannot be gained if there is underlying fear from the authority or if there are penalties, as is the case in traditional teaching. To have a successful teaching process, it is required that both the interest and enthusiasm of the pupils be triggered, which are undoubtedly provided by the activity of play. As the activity of play, along with its spontaneity and natural predisposition of the pupils, increases the intensity and desire to take part in it, it has an impact on pupils' desire for success, and it goes without saying that success leads to satisfaction. Satisfaction is a source of happiness and new motivation, which is realized completely spontaneously and without any imposition. The activity of play is also based on interest, which causes effort, and it is a fact that effort leads to development. Thus, all doubts that the activity of play is used to avoid effort and replace it with fun are confuted. The activity of play additionally provides a natural relationship with the syllabus, complementing it as a so-called artificial model of development and a personal program of the pupil, which appears as a result of the pupils' needs, opportunities and interests.

\section{The importance of the methodic conceptualization of the activity of play}

Activities of play are inherently defined as applicative and practically feasible. Their appropriate realization in the teaching process requires scientific and theoretical approach in the methodic setting, development and creation. To that end, all opportunities offered by didactics, methodology, developmental psychology and school pedagogy should be reviewed, and pupils' needs and natures, as well as the program concept of teaching, should be added to it. The connection between the theoretical placement and the practical implementation of the activity of play is realized through the following parameters: purpose and tasks, content, operations and rules, activities of the subjects, as well as the prospective results. Any activity of play based on a solid scientific and theoretical base shows high results in practice and thus it justifies its applicability. The value of the methodic conceptualization of the activity of play consists of the fact that it serves on the one hand, as a means which leads to the achievement of certain educational out results, and on the other hand, as a form through which pupils improve their knowledge, skills and capabilities. Through this approach, the activity of play is becoming the pupils' life practice more and more, which is also their way of learning. Methodically conceptualized activities of play are situated in the heart of the teaching process as significant movers of the active position of the pupil.

The Berlin school of structural theory offers a dateless model of formal structure of teaching based on the principles of didactics of teaching and learning. The main representative is Paul Hayman, who lists three dimensions of pedagogical intentionality in teaching process:

"pragmatic-dynamic pedagogical intention which should be used to affect the action, upon the pupil's wish (skills and habits);

b) cognitive-active pedagogical intentions, which are used to affect the pupil's opinion, and it relates to the receptive knowledge (simple information acquisition), intellectual/abstract (comprehending cause and effect relationships) and probability (the highest level of knowledge);

c) affective pedagogical intentions, used to act upon the emotions of the pupil, and these affect their wishes, experiences and assurance" (Vilotijevih 1999: 67).

This is the very pedagogical intentionality in the planning and relization of the teaching process offering a holistic approach in the development of the pupil's personality. The activity of play and its methodic conceptualization correspond to this definition. Its tendency is to create an array of activities of play, which will lead to an appropriate atmosphere for an appropriate development of all aspects of the pupil's personality. The activity of play is very frequently set in the same position as didactic plays. There are similarities and differences among them, but the main difference originates from the purpose towards which the purposes are aimed. The taxonomy of teaching units has a great contribution to solving this issue. According to Bloom, the taxonomy of teaching purposes, based on Guilford's Structure of Intellect Theory, has a great contribution to the scientific and theoretical foundation of the impact on the activity of play in the three fields: cognitive, affective, and psychomotor. A complementation of the structure and content of the syllabi in the first educational cycle as well as the opportunities which they offer as a first step in the process of implementation of the activity of play as a methodic concept are needed for this position. The basis created in the national documents should be upgraded with the concept of methodic articulation of the activity of play. The structrure of the concept based on macro-methodic and micro-methodic 
singularities should be completely methodically differentiated and clear for both teacher and pupil as main doers. Singularities in certain program fields are reflected in the design of certain methodic components of the activity of play, which are complemented in the basic set. The teacher and their pedagogical and didactic competences, which should constantly be developed, modernized and perfected, has the main role in the connection and distribution of theory into practice. All these components are mutually dependent and affect one another. They gain their place in teaching through an appropriate methodic conceptualization of the activity of play.

\section{Methodology of the Research}

The subject of this research aims at the analysis of the didactic prefix of the activity of play as a methodic concept in the first educational cycle in the Republic of Macedonia. The research has the character of an empiric research.

The purpose of the research is to test the didactic prefix based on methodic components in the organization and realization of the activity of play in the first educational cycle $(1,2$, and 3 grade) of the compulsory 9 -year primary education in the Republic of Macedonia.

\subsection{Research Hypotheses}

\subsubsection{General Hypothesis}

There is sufficient representation of methodic components in the organization and realization of the activity of play in the first educational cycle (1, 2, and 3 grade) of the compulsory 9-year primary education in the Republic of Macedonia.

\subsubsection{Separate Hypotheses}

The opinion that the professional preparation of the teachers for the organization and realization of activities of play is vital dominates among the respondents;

Most frequently, the contents of the syllabi of the first educational cycle of the primary education offer opportunities for creation of activities of play as a methodic concept in all program fields;

Methodic conceptualization and realization of the activity of play is in accordance with the pupils' developmental features as well as the syllabi;

A contemporary concept of the didactic materials which are applied in the realization of the activity of play needs to be created.

\subsection{Research Methods, Techniques and Instruments}

The methods of theoretical analysis, comprative and descriptive method are used in this research, and the following techniques are also applied: content analysis, monitoring and surveying.

\subsection{Research Sample}

The research was conducted on kindergarten educators and teachers from 16 primary schools in the Republic of Macedonia, so the collection and structure of the sample of respondents were easily supplied (kindergarten educators and teachers).

Table 1: Structure of the sample of primary schools

\begin{tabular}{|l|c|l|}
\hline \multirow{2}{*}{ Elementary School } & \multicolumn{2}{l|}{ Educators/Teachers } \\
\cline { 2 - 3 } & $\mathrm{f}$ & $\%$ \\
\hline Ljuben Lape & 4 & 2,6 \\
\hline Vlado Tasevski & 15 & 9,9 \\
\hline Dimo Hadzi-Dimov & 14 & 9,2 \\
\hline Lazo Trpovski & 5 & 3,3 \\
\hline Vera Ciriviri-Trena & 8 & 5,3 \\
\hline
\end{tabular}




\begin{tabular}{|l|l|l|}
\hline Petar Pop-Arsov & 13 & 8,6 \\
\hline Kole Nedelkovski & 13 & 8,6 \\
\hline 11 Oktomvri & 14 & 9,2 \\
\hline Kocho Racin & 10 & 6,6 \\
\hline Brakja Miladinovci & 10 & 6,6 \\
\hline Goce Delchev & 9 & 5,9 \\
\hline Vuk Karadzikj & 3 & 1,9 \\
\hline Malina Pop-lvanova & 11 & 7,2 \\
\hline Kiril i Metodij & 10 & 6,6 \\
\hline Vasil Glavinov & 9 & 5,9 \\
\hline Slavcho Stojmenski & 4 & 2,6 \\
\hline Total & 152 & 100.0 \\
\hline
\end{tabular}

\subsection{Analysis of the Results}

The importance of initial education for the organization and realization of the activity of play as a methodic concept

Certain prerequisities should be met for the requirements of the organization and realization of the activities of play. The initial education of the teaching staff from the first educational cycle refers to the representation of contents of this issue, the acquired practical experience as well as the application of the acquired knowledge during the professional engagement.

Table 2: Kindergarten educators' and teachers's attitudes regarding the importance of initial education for the organization and realization of activities of play as a methodic concept in the first educational cycle

\begin{tabular}{|l|l|l|l||l||l||}
\hline $\begin{array}{l}\text { The methodic concept of the activity of play in the } \\
\text { initial education was: }\end{array}$ & Not at all & Partially & Fully & Total \\
\hline Covered content-wise & F & 28 & 114 & 10 & 152 \\
\cline { 2 - 6 } & $\%$ & 18.4 & 75.0 & 6.6 & 100.0 \\
\hline With practical experience & F & 34 & 100 & 18 & 152 \\
\cline { 2 - 6 } & $\%$ & 22.4 & 65.8 & 11.8 & 100.0 \\
\hline Useful for current professional work & F & 18 & 86 & 48 & 152 \\
\cline { 2 - 6 } & $\%$ & 11.8 & 56.6 & 31.6 & 100.0 \\
\hline
\end{tabular}

Graph 1: Graphic representation of the percentage of kindergarten educators' and teachers' attitudes regarding the importance of the initial education for the organization and realization of activities of play as a methodic concept in the first educational cycle. 


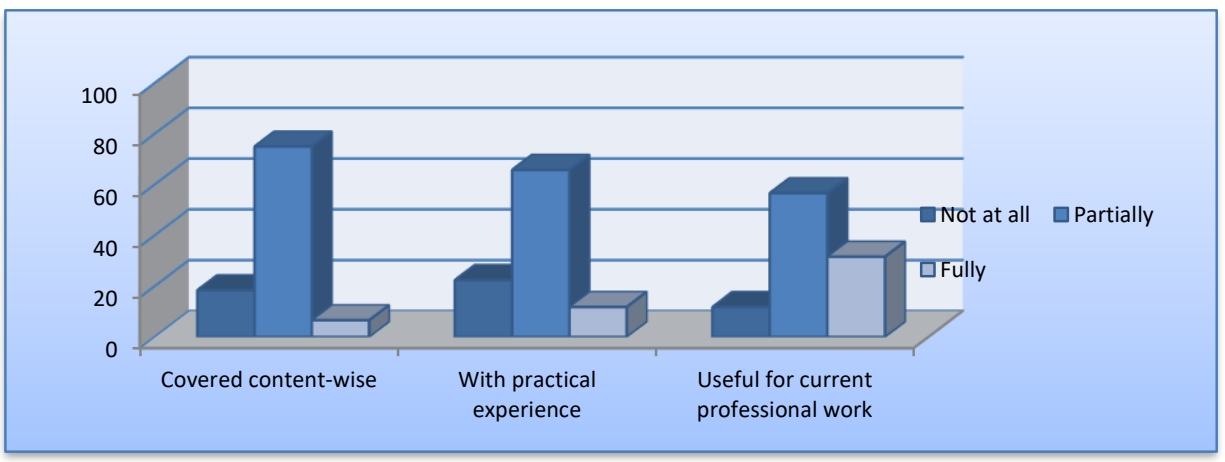

The results from Table 2 (Graph 1) show that in all three categories, the highest number of respondents believe that in the initial education there is partial content representation in the issue of the activities of play as a methodic concept. $18,4 \%$ of the respondents believe that there is no content representation of this topic during the initial education at all, and according to an insignificant number of respondents $(6,6 \%)$, the content representation was fully established during initial education.

When it comes to practical experience, the highest percentage of respondents $(65,8 \%)$ share the opinion that they have partially gained practical experience for the content, while $22,4 \%$ stated that they had not received any training during the initial education at all, and $11,8 \%$ of the respondents have been given compulsory practical experience from initial education.

In regards to the issue of the interdependence of initial education and current professional working, the greatest number of respondents $(56,6 \%)$ believe that initial education partially affects their current professional working. A small percentage, i.e. $11,8 \%$, believe that they have gained no practical experience during this period, but the rest of the respondents $(31,6 \%)$, suggest that the contents of this topic during the initial education are fully beneficial for their current professional working.

\section{The importance of trainings for professional improvement, made for the organization, and realization of the activity of play as a methodic concept}

The system of professional development aims at innovating the acquired knowledge by means of practical work and research activities, skills perfection, capabilities development and continuous teachers' development. The purpose of our research was also aimed at ascertaining the usefulness and application of teachers' trainings, as well as monitoring contemporary trands of these trainings in this field. In regards to the current situation about the trainings for teachers at the primary schools, the respondends answered as is shown in Table 3:

Table 3: Kindergarten educators' and teachers's attitudes regarding the importance of professional development trainings for the organization and realization of activities of play as a methodic concept 


\begin{tabular}{|c|c|c|c|c|c|c|}
\hline \multicolumn{2}{|c|}{ Trainings for professional improvement } & Not at all & Partially & Fully & Total & $\bar{X}$ \\
\hline \multirow[t]{2}{*}{ Covered content-wise } & $f$ & 32 & 93 & 27 & 152 & \multirow{2}{*}{$\bar{X}_{1}=2$} \\
\hline & $\%$ & 21.0 & ||61.2 & $\mid 17.8$ & $\mid 100.0$ & \\
\hline \multirow[t]{2}{*}{ Useful and applicable } & $\| f$ & 17 & 52 & 83 & 152 & \multirow{2}{*}{$\bar{X}_{2}=2.4$} \\
\hline & $\%$ & 11.2 & 34.2 & 54.6 & 100.0 & \\
\hline \multirow[t]{2}{*}{ Innovative and contemporary } & $f$ & 21 & ||61 & 70 & ||152 & \multirow{2}{*}{$\bar{X}_{3}=2.3$} \\
\hline & $\| \%$ & 13.8 & || 40.1 & 46.1 & $\mid 100.0$ & \\
\hline
\end{tabular}

Graph 2: A graphic representation of the percentage of kindergarten educators and teachers' regarding the importance of professional development trainings for the organization and realization of activities of play as a methodic concept in the first educational cycle.

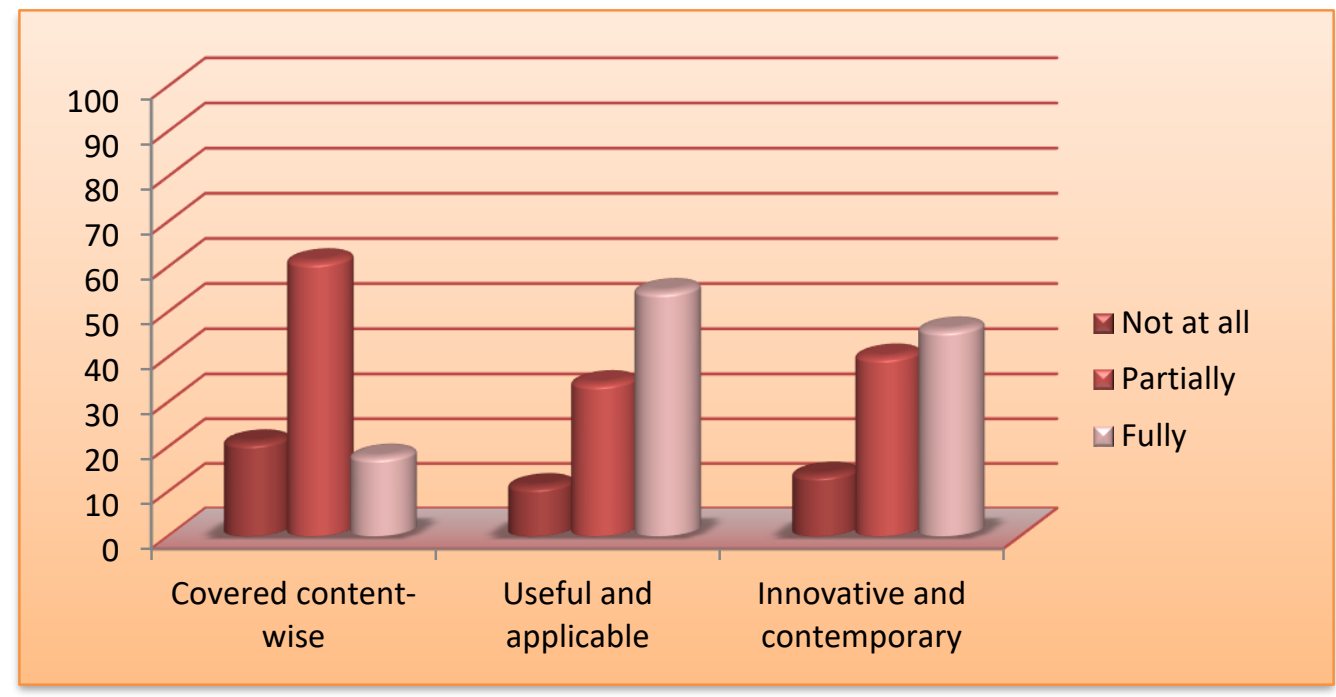

According to the data given in the table, the highest frequency of responses (93), i.e. $61,2 \%$ of the repondents, believe that professional development trainings for the organization and realization of activities of play as a methodic concept in the first educational cycle are partially represented. $21,1 \%$ of them share the opinion that trainings are not represented enough, and only $17,8 \%$ suggest complete representation of professional development trainings in this area. 
According to more than a half of the total number of respondents, the professional development trainings are very useful and applicable in their teaching practice. $34,2 \%$ of the respondents share the opinion that these are partially useful and applicable, and only $11,2 \%$ of the respondents state that the trainings do not have any application in everyday work.

As far as the issue of innovativity and application of professional development trainings is concerned, $46,1 \%$ of the respondents stated that these were fully innovative and contemporary, $40,1 \%$ believe they are partially represented, and $13,8 \%$ believe that the trainings are not innovative or contemporary at all.

\section{Graphic Scale 1}

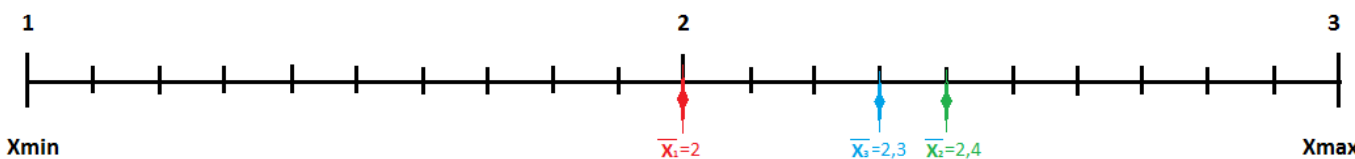

The analysis of data supplied by the calculated arithmetic mean of the three parts of the scale $\left(\bar{X}_{1}=2\right)$ represented on the graphic scale 1 has shown that the respondents believe that professional development trainings for the organization and realization of the activity of play as a methodic concept in the first educational cycle are partially represented. According to the mean value given $\left(\bar{X}_{2}=2.4 \mathrm{i} \bar{X}_{3}=2.3\right)$, it can be concluded that the repondents believe that the trainings are partially useful and applicable as much as they are innovative and contemporary even though they need to be aimed at the improvement of the teaching practice.

\section{Adequacy of the syllabi of the first educational cycle for the organization and realization of the activity of play as a methodic concept}

The syllabi of the first educational cycle are of great importance in the realization of the activity of play in the teaching process. The structure of the syllabi leads to content, directions and examples which give ideas for creating activities of play. The importance of this issuue, i.e. the adequacy of the syllabi in the teaching process, will be examined through the following question:

Table 3: Kindergarten educators' and teachers' attitudes regarding the adequacy of the syllabi of the first educational cycle for the organization and realization of the activity of play as a methodic concept

\begin{tabular}{|c|c|c|c|c|c|c|}
\hline \multicolumn{2}{|c|}{ The syllabi of the first educational cycle offer: } & Not true at all & Mostly false & Mostly true & Certainly true & ||Total \\
\hline \multirow[t]{2}{*}{ Content opportunities } & $f$ & 7 & 46 & 88 & 11 & 152 \\
\hline & $\%$ & 4.6 & 30.3 & 57.9 & 7.2 & 100.0 \\
\hline \multirow{2}{*}{ Certain directions } & $f$ & 6 & 65 & | 71 & $\mid 10$ & ||152 \\
\hline & $\%$ & 3.9 & 42.8 & 46.7 & 6.6 & $\mid 100.0$ \\
\hline \multirow{2}{*}{ Prepared solutions and examples } & $f$ & 25 & 45 & 75 & 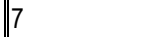 & ||152 \\
\hline & $\%$ & 16.5 & 29.6 & 49.3 & 4.6 & 100.0 \\
\hline
\end{tabular}

According to $57,9 \%$ of the respondents, what syllabi offer the most are content opportunities for the organization and realization of the activity of play in the first educational cycle, and according to a third of the respondents, $30,3 \%$, they greatly offer the content opportunities which are needed. A very small percentage of respondents, $11,8 \%$, have contrasting attitudes towards the content opportunities of the syllabi, i.e. $7,2 \%$ of them believe that it is fully true, and the rest of them, $4,6 \%$, believe it is not true at all. 
$46,7 \%$ of the respondents believe that the syllabi in the first educational cycle offer a certain direction, whereas $42,8 \%$ have a contrasting attitude and believe the syllabi do not offer it. In regards to this issue, we come across a low percentage of respondents, $6,6 \%$, who believe it is fully true, and 3,9\% who have stated that the syllabi do not offer any directions.

A large percentage of the respondents $(49,3 \%)$ share the opinion that the syllabi for this period mostly offer prepared solutions and examples of activities of play. On the other hand, the occurrence of 45 responses suggests that a third of the respondents believe that the syllabi do not offer prepared examples and solutions. Taking into account the low percentage of $16,5 \%$ and $4,6 \%$, we can conclude that a part of the respondents do not agree with their attitudes on the existence of prepared solutions and examples of activities of play in the syllabi.

\section{Didactic-methodic preparation of kindergarten educators and teachers in the process of creation and realization of the activity of play as a methodic concept}

This type of preparation serves as a guide according to which the teaching staff realize their ideas. Didactic-methodic preparation includes more aspects, but for the needs of our research, we have focused on: the starting subject and the starting approach as well as didactic materials application.

Ranking, Table 4.1: Kindergarten educators' and teachers' attitudes on where they start from in the process of creating and realizing the activities of play as a methodic concept

\begin{tabular}{|l|l||l|l||}
\hline $\begin{array}{l}\text { In the organization and realization of activities of play, } \\
\text { they start from: }\end{array}$ & & $\%$ & Ranking \\
\hline Syllabus & 102 & 67.1 & 1 \\
\hline \hline Pupils' interests & 49 & 32.2 & 2 \\
\hline \hline Current activities at the school & 1 & 0.7 & 3 \\
\hline \hline Total: & 152 & 100.0 & 3 \\
\hline
\end{tabular}

The ranking that we received based on the respondents' opinions about the starting point in the organization and realization of the activity of play shows that a high percentage of the respondents set off from the syllabus, while pupils' interests take up the second place, and the final place is taken up by the current activities at the school, due to the insufficient frequency of responses. The data given leads to the conclusion that the syllabus is still the most significant phenomenon for the creation and realization of the activity of play in the teaching practice.

Table 4.2: Kindergarten educators' and teachers' attitudes regarding the types of didactic materials and devices applied in the realization of the activity of play as a methodic concept

\begin{tabular}{|c|c|c|c|c|c|}
\hline \multicolumn{2}{|c|}{$\begin{array}{l}\text { Didactic materials and devices which are most frequently } \\
\text { applied in the activity of play: }\end{array}$} & \multirow{2}{*}{$\mid$\begin{tabular}{|l} 
Not at all \\
4
\end{tabular}} & \multirow{2}{*}{$\mid \begin{array}{l}\mid \text { Partially } \\
93 \\
\end{array}$} & \multirow{2}{*}{\begin{tabular}{|l} 
Yes, fully \\
55 \\
\end{tabular}} & \multirow{2}{*}{\begin{tabular}{||l|l} 
& Total \\
152
\end{tabular}} \\
\hline Didactic & $f$ & & & & \\
\hline & $\%$ & 2.6 & 61.2 & 36.2 & 100.0 \\
\hline \multirow[t]{2}{*}{ Natural } & $f$ & 3 & 78 & 71 & 152 \\
\hline & $\%$ & 2.0 & 51.3 & 46.7 & 100.0 \\
\hline \multirow[t]{2}{*}{ Purposely prepared } & $f$ & 1 & 56 & 95 & 152 \\
\hline & $\%$ & .7 & 36.8 & 62.5 & 100.0 \\
\hline \multirow[t]{2}{*}{ Combined } & $f$ & 1 & 49 & 102 & 152 \\
\hline & $\%$ & .7 & 32.2 & 67.1 & 100.0 \\
\hline
\end{tabular}


The respondents could give answers to different questions regarding how often and which didactic materials and devices they use in their teaching practice, and most of them, $67,1 \%$, use combined materials and devices which already consist of all the other offered categories of material types. It is especially important for the realization of the activity of play since the respondents have the opportunity to choose the most appropriate materials needed to meet the requirements of the nature of the content. However, in a combination of materials and devices, the teachers' and kindergarten educators' freedom is stressed, as well as their respect for their pupils' interests.

\section{Concluding remarks}

The analysis and interpretation of the data received from the research lead to several conclusions. In regards to the research for analyzing the views and beliefs of the educators and teachers, we received data that demonstrated the state and influence of the different aspects of the manner of organization and realization of the activity of play as a methodical concept. Those participants largely shared the views that they had been partially professionally trained for organizing and realizing the activity of play. The content offers, practical experience, as well as application in their present line of work, are not fully (i.e. partially) covered during their initial education, leading to the need for increased involvement of these aspects in the process of initial education of the future educators and teachers. This would all contribute towards more successful organizing and realizing of the activities of play in the first educational cycle of the mandatory nine-year primary education.

In regards to the issue of the trainings, the participants largely thought that they were partially covered, leading to the conclusion that they feel the need for their more frequent organization. In the analysis, the views of the teaching staff in regards to the appropriacy of the teaching programs demonstrate that the teaching programs largely offer content possibilities, defined directions and solutions/examples for the realization of the activity of play in a given subject. However, there is a need for clearer, more concise and specific recommendations for the realization of the activity of play. Kindergarten educators' and teachers' attitudes have emphasized didactic-methodic preparation as a significant question arising from this issue. This research has shown that in the preparation of the activity of play they mostly start from the syllabus, and even after they do so, they take into account pupils' interests and current happenings at the school. The data supplied in this research from the conducted questionnaire is aimed at proving the stated hypotheses, which are to verify the main hypothesis.

\section{References:}

[1] Adamceska, S. (1996). Aktivna nastava. Skopje: Legis.

[2] Benjamin, S. B. (1970). Taksonomija ili klasifikacija obrazovnih i odgojnih ciljeva. (Knjiga 1: Kognitivno područje, Preveo s engleskog I. Furlan). Beograd: Jugoslovenski zavod za proučavanje školskih i prosvetnih pitanja.

[3] Brady, L. (1992). Curriculum Development. Sydney: Prentice Hall.

[4] Child, D. (2004). Psychology and the Teacher. London: Continuum.

[5] Cudina-Obradović, M. (2008). Igrom do čitanja-igre i aktivnosti za razvijanje vještina čitanja. Zagreb: Školska knjiga.

[6] Curriculum Guidance for the Foundation Stage - Investing in our Future. (2000). London: Department for Education and Employment \& QCA.

[7] Edwards-Carol, Linda. (2006). The Creative Arts - A Process Approach for Teachers and Children. New Jersey: Pearson.

[8] Epstein, A. S. (2007). The Intentional Teacher. Washington, DC: National Association for the Education of Young Children.

[9] Joyce, B., Calhoun, E., \& Hopkins, D. (2002). Models of Learning - Tools for Teaching. Philadelphia: Open University Press.

[10] Kamenov, E. (1977). Intelektualno vaspitanje kroz igru. Beograd: Zavod za udzbenike i nastavna sredstva.

[11] Marsh, J. C. (1994). Kurikulum - temeljni poimovi. Zagreb: Educa.

[12] Moyles, J. (2005). The Excellence of Play. London: Open University Press.

[13] Packer-Isenberg, J., \& Renck-Jalongo, M. (2006). Creative Thinking and Arts-Based Learning. New Jersey: Pearson.

[14] Petersen, M., \& Velte, U. 500 5-Minuten-Spiele. Hamburg: Xenos Verlag.

[15] Poposki, K. (2000). Programiranje na vospitno-obrazovniot proces. Skopje: Pedagoski zavod na Makedonija.

[16] Porter, L. (2003). Young Children's Behaviour. London: Paul Chapman Publishing.

[17] Posner, J. G. (2004). Analyzing the Curriculum. New York: McGraw-Hill. 
[18] Quintero, P. E. (2009). Critical Literacy in Early Childhood Education. New York: Peter Lang.

[19] Riley, J. (2005). Learning in the Early Years. London: Paul Chapman Publishing.

[20] Thompson, I. (2005). Teaching \& Learning Early Numbers. New York: Open University Press.

[21] Trnavac, N. et al. (1991). Didakticke igre. Beograd: Zavod za uxbenike i nastavna sredstva, Pedagoska akademija za obrazovanie ucitela.

[22] Vilotijevih, M. (1999). Didaktika-Didakticke teorije i teorije ucenja-2. Beograd: Ucitelski fakultet.

[23] Ward, H., Roden, J., Hewlett, C., \& Foreman, J. (2006). Teaching Science in the Primary Classroom: A Practical Guide. London: Paul Chapman Publishing.

[24] Weinberger, J., Pickstone, C., \& Hannon, P. (2005). Learning from Sure Start. London: Open University Press.

[25] Wenham, M. (2006). Understanding Primary Science - Ideas, Concepts \& Explanations. London: Paul Chapman Publishing.

[26] Whitehead, M. (2003). Supporting Language and Literacy Development in the Early Years. Philadeplhia: Open University Press.

[27] Wood, E., \& Attfield, J. (2006). Play, Learning and the Early Childhood Curriculum. London: Paul Chapman Publishing

[28] www.see-educoop.net

[29] www.education-freedom.org

[30] www.unicef.org

[31] http://www.piaget.org/ 